T. MuraI : The Mental Health Problems Confronting the Students in the College Environment

環境に対する大学生の適応状況 (1)

建田大学 村 并孝 子

\section{H}

全人教育の一環としての 健康教育を効果的 に寒施するには，渨境面の諸因子が学生に与 える影雷を考虑することが必要であるリ。最 近，数育一般の問通として精神蕚生に関心が 示されているが，一つの大学においてこれを プログラムにのせるには，先つ，精神衞生の 面においてどの上うな問题が，その大学の学 生に共通なるのであるかを知らなければなら ないそれは，学生が，大学生としての自己 を碓立し，周囲の人々或いは集団に順応し諸 諸の生活活動を遂げていく遗程において生す ろ問㛹をいうのである。精神府生は，個人の 独自の性杽と周囲との間に生する軋れきをな くすということより，むしろ，あるがまの 状沿において，個々人がその人間性を十全的 に成長させてゆくことができるようにするこ とを目的としており，又，周囲の事情が不合 理な仕方で種々の障害となるここがないよう にすることに関心を出らのである，その為に は学園, 寮, その他, 工場, 村落等という特 定の場所で生活する人々がその環境にどのよ うに通応しているかということを知らなけれ ばならない。このような事情, 即ち, 適応状 沅がどのようにして客観的に把握できるかを 試みるために，津田熟大学において昭和 35 年 2 月に大学生を対象として調查を行つてみた。 以下にその方法, 結果, 批判を述へろ.

\section{I研究方法}

対象: 津田塾大学の学生中, 第一表に示す 人員に対して調査した。一年生の全員，二， 三年は全体の約半数つつである。

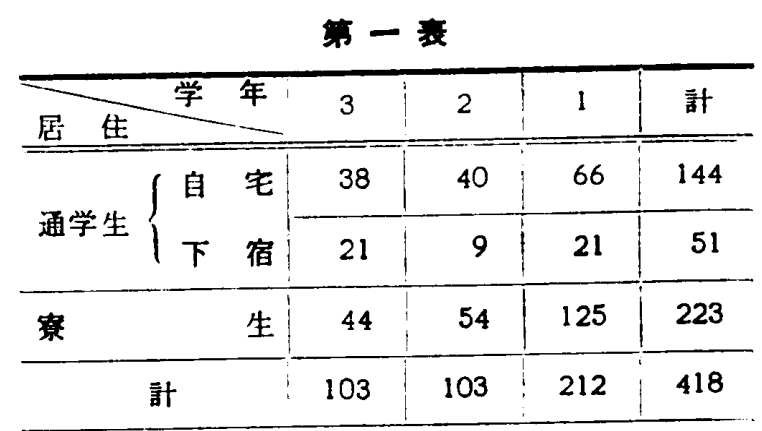

調査期日: 昭和 35 年 2 月. 尚, 津田塾大学 は女子の大学であり，都心を離えて武藏野に あり，専門学科は，英文学, 及び数学で学生 総数は約 900 名である。

調査表：一年次学生中 55 名に対し，大学生 として环境に適応していく過程において感し てきた種ヶの問題を，無記名で自由に記入さ せた。これを参照して問題を作成し第二表に 示すように10の領域 35 の項目に分類した。 本調査に括ける記入は，調查表について趣旨 を簡単に説明したのち 15 分間で行わせた。

資料の整理：各項目の反応数を領域別，学 年別，居住別にまとめ一覧表を作つた（第三 表).

第四表は各窅域にわたつての反応数の分布 を示するのである，反応率の高いるの，即ち， 問題をるつ者が多い順に順位をつけ, 便宜上 更に A B C D の四段階にわけた.

次に, 項目别の結果を反応率の高いるのか ら順にならべて，50\%以上を第一段階とし， 以下 $10 \%$ 毎に区ぎつて6段階に分けて適応度 を示すことにした。

学年別, 或は，住居別の相違をみるために 义 テストで有意差の有無を兒た。総反応数 
（）学年 (東・西・北) 暴，下宿（いつから下宿したか），自宅通学（片道通学時間 時間分） 次の項目のうち問題を感している項目に○印をつけて下さい「ての他」の項目は具体的に説明して下さい．

\begin{tabular}{|c|c|c|c|c|c|}
\hline 項 & O的記入㜀 & 説 明 欄 & 目 & ○印記入闌 & 説 明 排 \\
\hline 1. 家族関係 & & & 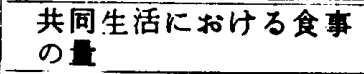 & & \\
\hline ホームシック & & I & $\begin{array}{l}\text { 共同生活における料理 } \\
\text { の方法 }\end{array}$ & & \\
\hline 家族から独立したい & & & 下宿の食事 & & \\
\hline その他 & & & その他 & & \\
\hline 2. 人生問通 & & & 7. 生活理境について & & \\
\hline $\begin{array}{l}\text { 自分の理想と現実社会 } \\
\text { のへだた }\end{array}$ & & & 通学時间が長い & & \\
\hline $\begin{array}{l}\text { 目標がない又は定まら } \\
\text { ない }\end{array}$ & & & 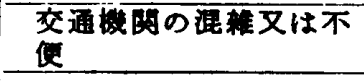 & & \\
\hline 目標と能カのへたたり & & & 自分の時間不足 & & \\
\hline 職業と結婚 & & & その他 & & \\
\hline その他 & & & 8. 宗教间趋 & & \\
\hline 3. 社会的㮌応 & & ! & 家の宗数と自分の宗数 & & \\
\hline 社会的劣等感 & & & 信仰を得たい & & \\
\hline \multirow{2}{*}{ 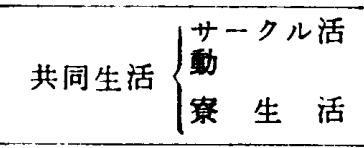 } & & & $\begin{array}{l}\text { キリズドの洗礼につ } \\
\text { いて }\end{array}$ & & \\
\hline & & & その他 & & \\
\hline 一人になる時間を望む & & & 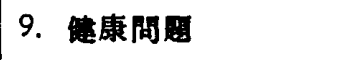 & & \\
\hline その他 & & & 運動不足 & & \\
\hline 4. 情緒的問通 & & & 疲労 & & \\
\hline 自分の感情の処理 & & & スボーツをする時間 & & \\
\hline 友情 & & & スボーツをする体力 & & \\
\hline 受 情 (異性間) & & & 虚弱 & & \\
\hline その他 & & & その他 & & \\
\hline 5. 学問・勉強の問題 & & & 10.经济問题 & & \\
\hline 学校の選択 & & & $\begin{array}{l}\text { 入学時と現在の家庭の } \\
\text { 㳗沙状態の相透 }\end{array}$ & & \\
\hline $\begin{array}{l}\text { 蒠分の目標と学問分野 } \\
\text { の択 }\end{array}$ & & & アルンイトの時間がな & & \\
\hline 学課目選抧 & & & フルバイトによる披弟 & & \\
\hline その他 & & & その他 & & \\
\hline 6. 食 生 活 & & & & & \\
\hline 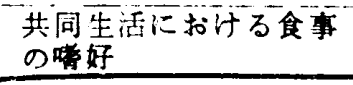 & & & & 1 & \\
\hline
\end{tabular}


理竟に対する大学生の適庍状況

\begin{tabular}{|c|c|c|c|c|c|c|c|c|c|c|c|c|c|c|}
\hline & & 学 & 年 & 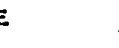 & 別 & & 居 & 住 & 别 & （下宿 & 宿を & () & & \\
\hline & 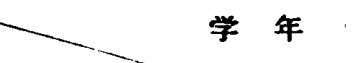 & & & & & I 学 & 年 & I学 & 年 & II 学 & 年 & 平 & & 㚬 \\
\hline 項 & - & & & & & $7=$ & 寮生 & 生岛 & 暴生 & . & 生 & 通学 & 生 & 暴生 \\
\hline 家 & ホームシツク & 31.2 & 19.4 & 9.7 & 22.5 & & 42.4 & & 29.6 & $0_{i}$ & 18.2 & $S D$ & 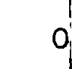 & \\
\hline 裂 & 立 ᄂ & 14.6 & 12.6 & $\begin{array}{r}* * * * \\
26.2\end{array}$ & 17.1 & 15.2 & 14.4 & 15.0 & 9.3 & $29.0^{\prime}$ & 22.7 & & 18.7 & 14.8 \\
\hline 係 & その他 & 7.5 & 14.5 & 17.5 & 11.8 & 7.6 & 8.8 & $17.5: 1$ & 12.9 & 14.1 & 20.5 & $S D$ & 11.3 & 12.1 \\
\hline 人 & 想と㻈实社会 & $316^{\prime}$ & 26.2 & 29.1 & 29.6 & 28.8 & 33.6 & 30.012 & $24.1\}$ & $29.0^{\prime}$ & 31.8 & & 9.2 & 3 \\
\hline et & 自鲧ない又は定まら & 38.2 & 43.6 & 39.8 & 40.0 & 45.5 & 32.8 & 52.53 & 38.9 & 44.8 & 41.0 & $S D$ & 47.2 & 35.8 \\
\hline 4 & 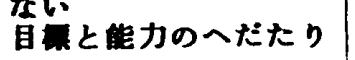 & 38.2 & 36.9 & 35.0 & 37.1 & 19.7 & 49.6 & 27.5 & 40.7 & 31.6 & 34.1 & $S D$ & 25.0 & 44.4 \\
\hline 周 & 而萧と蛙格 & 24.5 & $*, * * * * 1$ & $\begin{aligned} *, * * * \\
48.5\end{aligned}$ & 32.9 & 27.3 & 24.8 & 27.53 & 33.3 & 47.4 & 54.5 & & 32.6 & 32.7 \\
\hline 用 & その他 & 0.5 & 1.0 & 2.9 & 1.2 & 0 & 0.8 & 0 & 1.9 & $d$ & 6.8 & & 0 & 2.2 \\
\hline 社 & 社会的劣等怘 & 25.5 & 23.3 & 20.4 & 23.7 & 28.8 & 24.8 & $20.0^{\prime}$ & 18.5 & 18.4 & 22.7 & & 23.6 & 22.9 \\
\hline 会 & 共网生活(サークル活牙) & 30.6 & 20.4 & 24.2 & 26.5 & 42.4 & 22.4 & 35.0 & 11.1 & 31.6 & 15.9 & $S D$ & 37.5 & 18.4 \\
\hline 的 & 共同生活（富生活） & 29.2 & 17.5 & 18.4 & 23.6 & & $45 \cdot 6$ & 0 & 33.3 & o & 41.0 & $S D$ & 9 & 41.7 \\
\hline is & 一人になる時间を望む & 37.7 & 31.1 & 33.0 & 34.9 & 10.6 & 57.6 & 17.5 & 44.4 & 29.0 & 36.4 & $S D$ & 18.1 & 50.0 \\
\hline 応 & その他 & 1.4 & 1.9 & 1.9 & 1.7 & 6.1 & $0.8 !$ & 2.5 & 1.9 & 2.6 & 0 & & 4.2 & 0.9 \\
\hline 请 & 自分の必供の处理 & 51.5 & 3.6 & 38.8 & $46.4 \|$ & 53.0 & 49.6 & 47.5 & 40.7 & 42.1 & 41.0 & & 48.6 & 45.5 \\
\hline 的 & & 62.7 & 46.6 & 39.8 & 53.0 & 66.7 & 64.0 & 42.5 & 46.3 & 36.8 & 43.2 & & 52.0 & 55.4 \\
\hline 問 & 情（畏性间） & 26.4 & 31.1 & 39.8 & 31.0 & 18.2 & 32.0 & $25.0_{1}^{\prime}$ & 29.6 & 52.6 & 27.3 & & 29.2 & 30.5 \\
\hline 通 & その他 & d & 0 & 0 & 0 & 0 & 1.6 & 0 & 0 & 0 & 0 & & O & 0.9 \\
\hline の & $\therefore \square$ & 30.6 & 25.2 & 26.2 & 28.2 & 34.8 & 29.6 & $27.5^{\prime}$ & 20.4 & $29.0^{\prime}$ & 29.6 & & 31.2 & 27. \\
\hline 间 & $\begin{array}{l}\text { 自分の目的と学阔分里 } \\
\text { の造抧 }\end{array}$ & & 56.3 & 52.5 & 56.0 & 48.5 & 61.6 & 47.5 & 62.9 & 50.0 & 45.5 & & 48.6 & 59.0 \\
\hline & 学目通択 & 17.5 & 11.6 & 3.9 & 12.6 & 16.7 & 16.0 & 10.0 & 12.9 & 2.6 & 6.8 & & 11.1 & 13.4 \\
\hline 虽国 & その他 & 1.9 & 2.9 & 5.8 & 3.1 & 0 & 2.4 & 2.5 & 3.7 & 2.6 & 11.4 & & 1.4 & 4.5 \\
\hline 食 & $\begin{array}{l}\text { 共同生活におけ万食事 } \\
\text { の好 } \\
\text { 基同生活におけ万表 }\end{array}$ & 29.7 & $19 * *$ & $\begin{array}{r}* * * * k \\
10.7 ! \\
*\end{array}$ & 22.4 & 7.6 & 45.6 & 5.0 & 33.3 & 0 & 25.0 & $S D$ & 4.9 & 9 \\
\hline & の量 & 16.5 & 12.6 & 8.7 & 13.6 & 3.0 & 24.8 & 0 & 22.2 & 26. & 18.2 & $S D$ & 2.1 & 22.9 \\
\hline 生 & 共同生活にお & 14.6 & 17.4 & 16.5 & 15.8 & 6.1 & 40.8 & 0 & 33.3 & 7.9 & 25.0 & $S D$ & 4.9 & 24.6 \\
\hline & 芐宿の食事 & 3.3 & 1.0 & 5.8 & 3.4 & 0 & & 0 & & 0 & 0 & & ; & 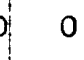 \\
\hline 活 & その他 & $1.4^{i}$ & 2.9 & 8.7 & 3.6 & $c^{\prime}$ & 2.4 & 0 & 5.6 & 10.5 & 4.5 & & 2.8 & 3.6 \\
\hline 生に & 通学時間が長い & 21.2 & 22.3 & 27.2 & 3.0 & 63.6 & 0. & $55.0^{\prime}$ & 0 & 68.4 & $0^{\prime}$ & $S D$ & 62.5 & 5 \\
\hline & 交甬機関の混又は不 & ***.***** & 31.1 & 31.0 & 37.2 & $59.1_{i}^{1}$ & 34.4 & 60.0 & 11.1 & 55.3 & 15.9 & $S D$ & 58.3 & 325.1 \\
\hline w. & 自分の時間不足 & 38.6 & 49.5 & 44.6 & 43.2 & 51.5 & 31.2 & 50.0 & 51.9 & 52.6 & 36.4 & $S D$ & 51.3 & 37.2 \\
\hline 境て & その他 & 6.1 & 2.9 & 4.9 & 5.0 & 3.0 & 8.8 & 0 & 5.6 & 5.3 & 0 & & 2.8 & 3.3 \\
\hline
\end{tabular}




\begin{tabular}{|c|c|c|c|c|c|c|c|c|c|c|c|c|c|}
\hline 宗 & 家の宗教々日分の宗教 & 2.4 & ***. & 9.7 & 4.6 & & 4.0 & 2.5 & 5.6 & 7.9 & 11.4 & 3.5 & 5.8 \\
\hline 教 & 䛿仰を得たい & 21.2 & $23.3 i$ & 19.4 & 21.3 & 21.2 & 18.4 & 20.0 & 24.1: & 15.8 & 22.7 & 19.4 & 20.6 \\
\hline 問 & $\begin{array}{l}\text { キリスト教の洗礼につ } \\
\text { いて }\end{array}$ & 7.1 & 10.7 & 7.8 & 8.2 & 4.5 & $9.6 !$ & 15.0 & 7.4 & 10.5 & 4.5 & 9.0 & 8.0 \\
\hline 题 & その他 & 5.7 & 6.8 & 6.8 & 6.3 & 3.0 & 8.0 & 9 & 12.9 & 5.3 & 9.1 & 2.8 & 9.4 \\
\hline & 運動不足 & 55.2 & 49.5 & 18.5 & 52.1 & 33.3 & 68.0 & 32.5 & 64.8 & 44.8 & $59.1 S D$ & 36.1 & 65.5 \\
\hline & 疲労 & 21.7 & 18.4 & 15.5 & 19.3 & 30.3 & 18.4 & 22.5 & 12.9 & 23.7 & $11.4 S D$ & 26.4 & 15.7 \\
\hline & スポーツをする時間 & 31.1 & 25.2 & 8.1 & 28.9 & 30.3 & 32.0 & 22.5 & 27.8 & 36.8 & 27.3 & 29.8 & 30.0 \\
\hline & スポーツをする体力 & 12.7 & 5.8 & & 9.0 & 13.6 & 12.8 & 2.5 & 2.3 & 5.3 & $2.3^{\prime}$ & 8.3 & 9.4 \\
\hline Pl & 成弱 & 5.7 & 12.6 & 4.9 & 7.2 & 4.5 & 6.4 & 7.5 & 16.7 & 2.6 & 9.1 & 4.9 & \\
\hline & 嘎眠不足 & 18.4 & 21.3 & 29.1 & 21.8 & 18.2 & 16.0 & 22.5 & 22.2 & 31.6 & 25.0 & 22 & 19.3 \\
\hline & その地 & 0 & o) & & 0 & 0 & 2.4 & 0 & 0 & 0 & 0 & d & $1 \cdot 3$ \\
\hline 経 & $\begin{array}{l}\text { 入学時と現在の家誕の } \\
\text { 程清䳌の相連 }\end{array}$ & 9.4 & 7.8 & 10.7 & 9.3 & 4.5 & 11.2 & & 11.1 & 14.1 & $11.4 S D$ & 5.6 & 11 \\
\hline 涪 & $\begin{array}{l}\text { アルパ } \\
\text { W }\end{array}$ & 12.5 & 10.7 & 8.7 & 11.1 & 6.1 & 16.0 & 5.0 & 14.8 & 10.5 & $9.1 S D$ & 6.9 & 14.3 \\
\hline 問 & フルバイトによる夜 & 5.2 & 15.5 & 15.5 & 10.4 & 9.1 & 2.4 & 25.0 & 9.3 & 15.8 & $9.1 S D$ & 15.3 & 5.4 \\
\hline & その他 & 6.1 & 5.8 & 2.9 & 5.2 & 3.0 & 8.0 & & 11.1 & 2.6 & 4.5 & 2.1 & 8.0 \\
\hline
\end{tabular}

*，一年生との間に有意差のるあことを示す，SD は寮生との間に有意差のあることを示す

**, 二年生

***，三年生

(数字は百分革)

策四㖖

領城别反店建順位比较

\begin{tabular}{|c|c|c|c|c|c|c|c|c|c|}
\hline \multirow{2}{*}{$\begin{array}{r}\text { 段 } \\
\text { 階 } \\
\end{array}$} & \multirow{2}{*}{ 領 } & \multirow{2}{*}{ 域 } & \multicolumn{2}{|r|}{ 全拥查人只 } & 418 & \multicolumn{2}{|c|}{ 通学生 144} & \multicolumn{2}{|c|}{ 皮 223} \\
\hline & & & 順位 & 反度事 \% & $\begin{array}{c}\text { 反底回数 } \\
(3824) \\
\end{array}$ & 順位 & $\begin{array}{c}\text { 反底家 \% } \\
(1227)\end{array}$ & 喕位 & $\begin{array}{c}\text { 反充事 \% } \\
(2163)\end{array}$ \\
\hline \multirow{3}{*}{$\mathbf{A}$} & 人 生 問 & & 1 & 15.27 & 584 & 2 & 15.72 & 2 & 15.06 \\
\hline & 健 康 問 & & 2 & 15.13 & 579 & 4 & 15.07 & 1 & 15.52 \\
\hline & 情 緒 的 問 & & 3 & 14.30 & 547 & 3 & 15.24 & 4 & 13.67 \\
\hline \multirow{3}{*}{ B } & 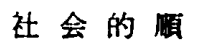 & 庆 & 4 & 12.08 & 462 & 6 & 9.69 & 3 & 13.81 \\
\hline & 生 活 環 & 境 & 5 & 11.85 & 453 & 1 & 20.53 & 7 & 7.07 \\
\hline & 学問勉强の問 & & 6 & 10.94 & 418 & 5 & 10.83 & 5 & 10.72 \\
\hline \multirow{2}{*}{ C } & 生 & 活 & 7 & 6.43 & 246 & 10 & 1.71 & 6 & 9.24 \\
\hline & 家 族 閶 & 係 & 8 & 5.65 & 216 & 8 & 3.58 & 8 & 6.33 \\
\hline \multirow{2}{*}{$\mathbf{D}$} & 宗 教 問 & 題 & 9 & 4.42 & 169 & 7 & 4.07 & 91 & 4.52 \\
\hline & 程 阔 & 題 & 10 & 3.92 & 150 & 9 & 3.50 & 10 & 4.02 \\
\hline
\end{tabular}


第五表

項目别反店事植位表

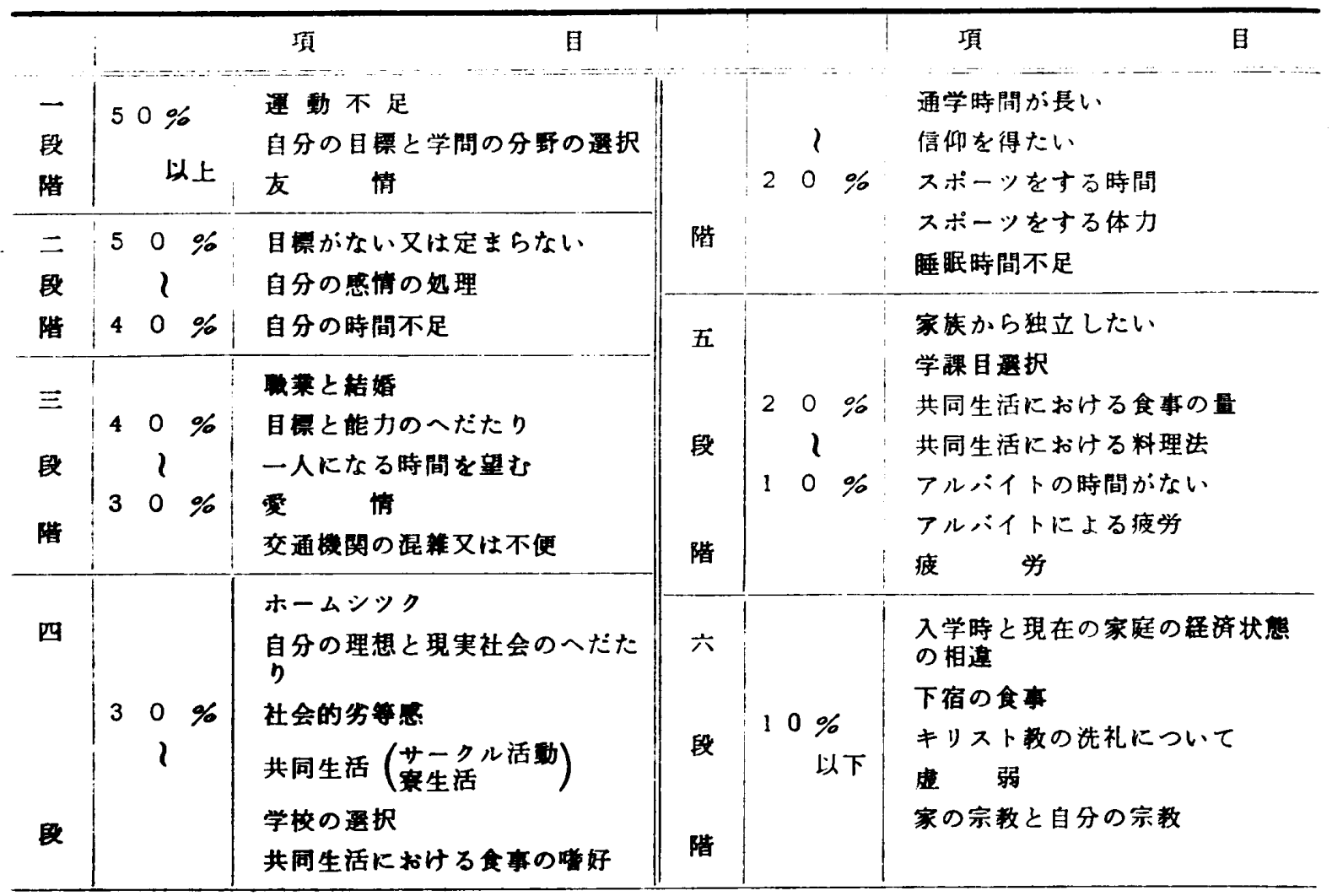

仕，3,824で一人平均 9.2 コ○印をつけている ことになるこの分布を第一罒に示す。

国

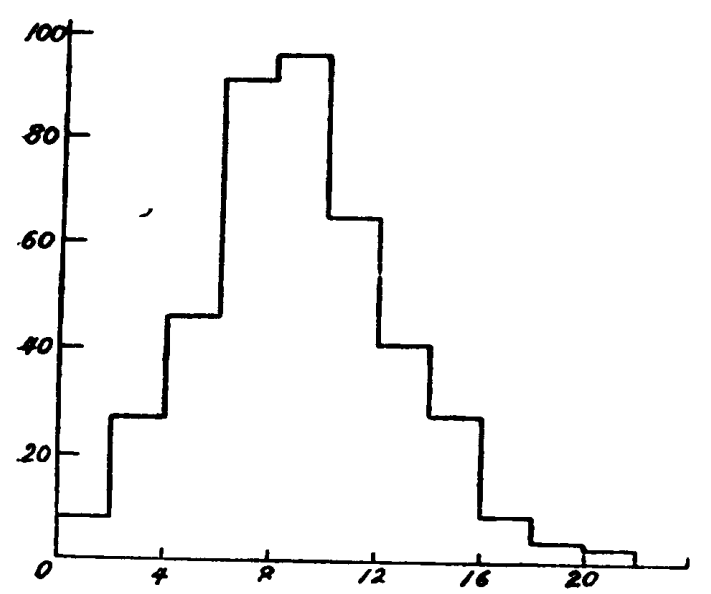

III㰴果と教漂

第六表は，調査の結果を領域別にまとめた るのである.この表から，大学全体として考 秘すべき領域は，(人生問題)，(健康問題）で
あることが知れる．次に一般的な間題は（学 問勉強の問題）であり。これら三つの間通に 対しては，motivation の不足を補い，铺導， 相談等によつて或程度解决の道が開けよう。 (社会的順応) と（情緒的問題）は，学年が進 むにつれて道応度がふえているが，これは共 同生活の効果によるるのであろう，又，主と して通学生が，(生活環境）を問題にしている のは，学校の地理的環境がその主要な原因で あると思觉る。（社会的順応）はどちらかと いえば，寮生の問題である。（家族関係）と （食生活）は，不通底度が低く，かつ，学年が 進むにつれて問題をるつ人も减つているが， (宗教問題) と（柽阂問通）は，問題にする人 は少ないが，学年と共に减つていない点が注 目される。

項目別に調へててみると，年令と共に增加す る度合を示するの，家庭を離れて共同生活を することの効果が示されているるの，居住別 
第六丧

領域別学年差, 通学生 - 案生差比校

\begin{tabular}{|c|c|c|c|c|c|}
\hline 対 & 向 懅 階 & $\mathbf{A}$ & $\mathbf{B}$ & C & $\mathbf{D}$ \\
\hline $\begin{array}{l}(!) \\
\text { 学 }\end{array}$ & 比較的差が少ない & $\begin{array}{l}\text { 人生間题 } \\
\text { 健康問通 }\end{array}$ & 学問勉強の問間 & & $\begin{array}{l}\text { 宗教問通 } \\
\text { 程済問通 }\end{array}$ \\
\hline $\begin{array}{l}\text { 年 } \\
\text { 別 } \\
\text { 傾 }\end{array}$ & $\begin{array}{l}\text { 項目によつて適応度がふ } \\
\text { えるものと減るものがあ } \\
\text { る }\end{array}$ & 情楮問通 & 生活環境 & & \\
\hline 向 & 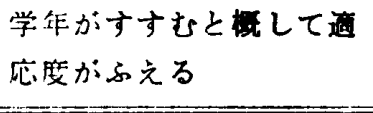 & & 社会的順応 & $\begin{array}{l}\text { 家族閏係 } \\
\text { 食生活 }\end{array}$ & \\
\hline $\begin{array}{l}(2) \\
\text { 通 } \\
\text { 学 }\end{array}$ & $\begin{array}{l}\text { 两方亡も大体同し恖応度 } \\
\text { をむしている }\end{array}$ & $\begin{array}{l}\text { 健康問通 } \\
\text { 人生問通 } \\
\text { 情緒問題 }\end{array}$ & 学問勉强の赒宙 & & $\begin{array}{l}\text { 玨済問闑 } \\
\text { 宗数間通 }\end{array}$ \\
\hline $\begin{array}{l}\text { 生 } \\
\text { 察 }\end{array}$ & $\begin{array}{l}\text { どちらかといえば通学生 } \\
\text { の問逨 }\end{array}$ & & 生活環境 & & \\
\hline $\begin{array}{l}\text { 生 } \\
\text { 差 }\end{array}$ & $\begin{array}{l}\text { どちらかといえば尊生の } \\
\text { 問題 }\end{array}$ & & 社会的順庆 & $\begin{array}{l}\text { 家族网保 } \\
\text { 企生活 }\end{array}$ & \\
\hline
\end{tabular}

に問題差が示されるもの, 或いは, 学年別居 住別に関倸なく遍在するるのなどの種々な項 目に分類される．第三表及び第七表により （家族から独立したい）(ホームシック）(結婚 そ職業）(愛情) など年令的成長の面からいつ て当然と思える傾向を示している。

（寮生活）（ホームシック）（友情）（一人に なる時間を望む）（自分の感情の処理）（生活 環境）（共同 生活に㧍ける 食生活）等の項目 は，いつれる学年がすっむにつれて逼応度が 著しく增加している。共同生活をとおして maturity に到達する過程が 示されていると思 える・

通学生と寮生の間に顕著な 差がみられる項 目が三つある。まつ愛情であるが，尞生は， 一年 $32 \%$ で，学年毎に減るが，通学生は，一 年 $18 \%$ ，二年 $25 \%$ ，三年は $52.6 \%$ と一年の 3 倍近くの者が問題を感じている。（目標がない 又は定まらない）では通学生の間にきわだつ て問题が多く（目標と能力のへだたり）で は，反対に寮生の間に多い。これを学年差に
特いて 検べると，前者は，一学年の 通学生 は $19.7 \%$ で寮生は 49.6\%であるが，通学生は 学年毎に增し寮生は減つてゆき，三年では殆 んど同じく $30 \%$ 余りになつている. 後者は， 通学生はいつれれの学年す $45 \%$ 以上で，寮生 は，上級生の方が，少しつ問䔔を多くもち， 32.8\% から 38.9\%，41.0\%になつてきている。 この三つの項目は，直接環境と関係を有する すのではないので，更に考虑を要するところ である。

学年差がないのは，(自分の目標と学問分野 の選択）というのであるが，これは反応率も 高く，日本における大学教育のあり方という 見地から考えなければならない問題であると 思5.（学校の選択）は反応率はずつと低いけ れど，学年差がみられずやはり同じようなこ とが関連していると見てよい（運動不足） は，通学生よりも寮生に多く，全体としても， 運動に対する欲求が強く示されている. 三年 では，通学生の反度率が急に高くなつてい る 2)。これには色々な理由，例えば，高校 


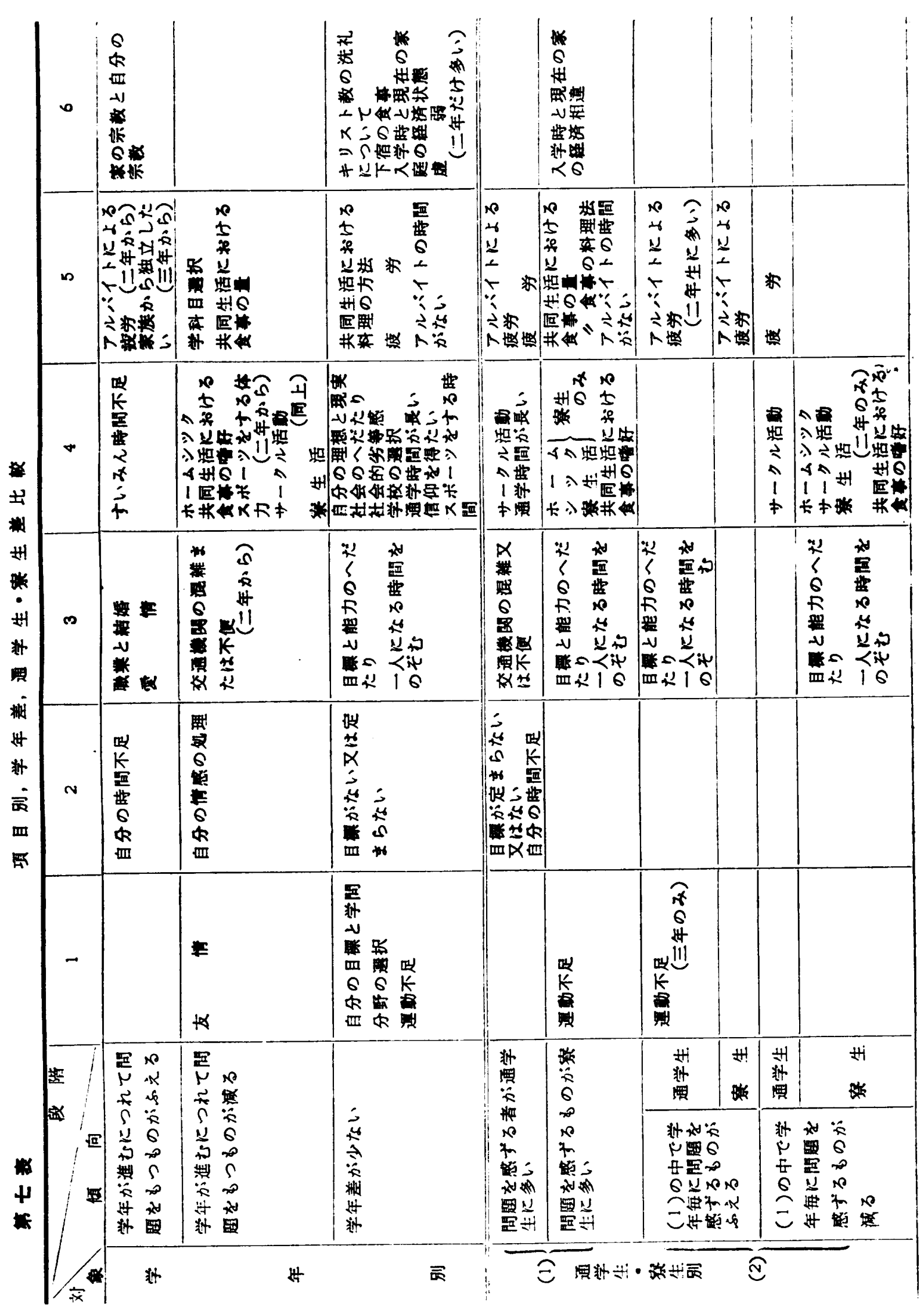


時代に運動を余りしなかつたこと、施設が割 合に充分であること，体育への理解が深めら れること，学業等が忙がしくて運動ができに くいこと等が考兄られる。

（その他）の項目には次のような問題が含ま れている。

家族関保一家族間の不和，病気，世代意識の 差等。

人生問題一価値判断, 結婚, 就職等. 社会的順応一自分の性格，対人関係等. 情緒的問題一人間関係等.

学問勉強の問題一勉強方法, 試験の失敗, 劣 等感等.

食生活一栄養不足，時間不規則等。

生活環境一騷音，個室が欲しい等。

宗教問題一宗教の本質，結婚 と宗教，信仰 と生活.

煡康問題一不眠症.

経済問題一適当なアルパイトが欲しい，家 の程済等。

\section{IV 結 酛}

津田塾大学におけ一年, 二年, 三年の学 生 418 名を対象として調査研究をした結果， 適応状況についての問題点及び諸傾向が 明白 にされた，即ち，各領域について，全対象，通 学生, 寮生別に反応率順位を決定し, 更に, 四 段階にわけた。又，各項目を全被調査人員の示 した反応率により六段階に分類をした。この 順位及び段階を基準として，領域別及び項目
別に，学年差，居住別差についての比較を行 つて，夫々学年毎に適応度がましてくるもの， 減つてくるもの，学年差，居住別差の少ない ものなどが表示された。これはこのグルー プに属する一員としての個人の状況を考える 一つの基点となりうるものである，又，大学 が，クループ討議や個人面接を行う場合，こ の調查によつて示された傾向が，学生個人個 人にとつて有利な場合であるのか，或は，不 当な handicap になつているのか等の参考点 を見出す一つのてがかりともなり得ると思え る. 通学生と蕠生の比校を行うことにより， 此の調査の信頼度を認めることができた。即 ち，(学間勉強の問題）（家族関係一ホームシ ツクを除いた域合)，(人生 問題)，（健康問

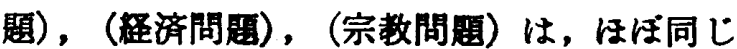
反応率を示している。

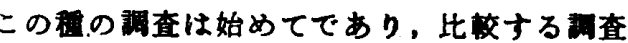
資料も見出されず，現在の状渑を知万のに役立 つのみである．同じ学生を進学する度に稀查し て变旡をみること，或いは，他の大学に同棣の 調査を試みて比较するなどして更に意竗梁い結 果を得るように努めたいと考えている。

\section{照}

1) E. Berchet: Int. Jour. Health Educ., 3. 16, (1960).

2）津田整大学においては第三学年次に於いて体育 の授策を䢙一時間実施している。 


\title{
Mental Health Problems Confronting the Students in the College Environment
}

\author{
By \\ T. Murai ; Tsuda College
}

In order to find a method of measuring mental health, a study was made on the relationship between students and their university environment, using an inventory devised for that purpose. The study included 418 college women of different school years. All the answers were checked and calculated for each of 35 items and also for each of ten areas. Their percentages were listed in Table 3, and served the basis for the ranking of areas and of items of the whole subjects in Tables 4 and 5 . The two tables, Tables 6 and 7, were prepared to show the tendencies of their mental health problems according to the school years and also to the two different residential groups.

\section{A Study on Mental Health of High School Boys and Girls from the Viewpoint of Suicide (3)}

By

\section{A. Kawabata, \& K. Takagi ; Kyoto University}

A. Katsube ; Nagoya University

A comparative study between group A (those who have attempt) among 999 of senior (second grade) boys and girls was conducted to investigate how such factors as personality, environment, are related to their suicidal attempts.

In the first report, emotional instability and social maladjustment were noticed in group $\mathrm{A}$ as to the personality difference, and no marked difference was discriminated as the environmental difference observed in family construction in this study.

In the second report, there were some relations among environment, family status, personality and their suicidal attempts, but no relations with economical status of their family.

In this report (3), there were several problems to investigate etc. which has remained in $(1) \sim(2)$ reports, and as result, there were a pretty difference between group $A$ and group $B$. 